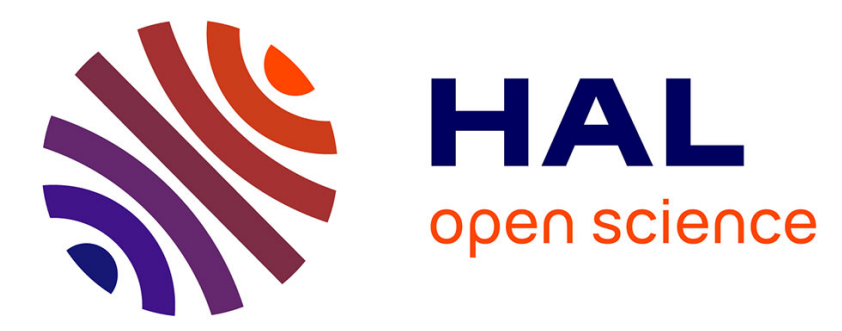

\title{
Low cycle fatigue behaviour of a precipitation hardened $\mathrm{Cu}-\mathrm{Ni}-\mathrm{Si}$ alloy
}

\author{
Maxime Delbove, Jean-Bernard Vogt, Jérémie Bouquerel, Thierry Soreau, \\ François Primaux
}

\section{- To cite this version:}

Maxime Delbove, Jean-Bernard Vogt, Jérémie Bouquerel, Thierry Soreau, François Primaux. Low cycle fatigue behaviour of a precipitation hardened $\mathrm{Cu}-\mathrm{Ni}-\mathrm{Si}$ alloy. International Journal of Fatigue, 2016, 92, pp.313-320. 10.1016/j.ijfatigue.2016.07.019 . hal-01376424

\section{HAL Id: hal-01376424 \\ https://hal.science/hal-01376424}

Submitted on 4 Oct 2016

HAL is a multi-disciplinary open access archive for the deposit and dissemination of scientific research documents, whether they are published or not. The documents may come from teaching and research institutions in France or abroad, or from public or private research centers.
L'archive ouverte pluridisciplinaire HAL, est destinée au dépôt et à la diffusion de documents scientifiques de niveau recherche, publiés ou non, émanant des établissements d'enseignement et de recherche français ou étrangers, des laboratoires publics ou privés.

\section{(1) (1) $\$$}

Distributed under a Creative Commons Attribution - NonCommercial - NoDerivatives| 4.0 


\section{Accepted Manuscript}

Low cycle fatigue behaviour of a precipitation hardened $\mathrm{Cu}-\mathrm{Ni}-\mathrm{Si}$ alloy

Maxime Delbove, Jean-Bernard Vogt, Jérémie Bouquerel, Thierry Soreau, François Primaux

PII:

S0142-1123(16)30223-7

DOI:

http://dx.doi.org/10.1016/j.ijfatigue.2016.07.019

Reference:

JIJF 4038

To appear in:

International Journal of Fatigue

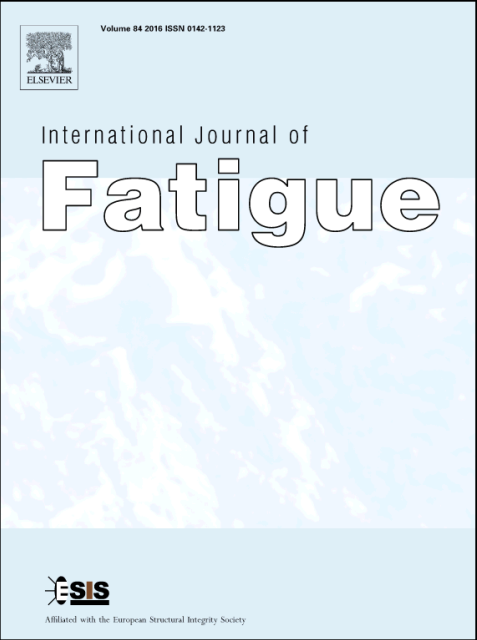

Received Date: $\quad 8$ June 2016

Revised Date: $\quad 22$ July 2016

Accepted Date: $\quad 25$ July 2016

Please cite this article as: Delbove, M., Vogt, J-B., Bouquerel, J., Soreau, T., Primaux, F., Low cycle fatigue behaviour of a precipitation hardened Cu-Ni-Si alloy, International Journal of Fatigue (2016), doi: http://dx.doi.org/ 10.1016/j.ijfatigue.2016.07.019

This is a PDF file of an unedited manuscript that has been accepted for publication. As a service to our customers we are providing this early version of the manuscript. The manuscript will undergo copyediting, typesetting, and review of the resulting proof before it is published in its final form. Please note that during the production process errors may be discovered which could affect the content, and all legal disclaimers that apply to the journal pertain. 


\title{
Low cycle fatigue behaviour of a precipitation hardened $\mathrm{Cu}-\mathrm{Ni}-\mathrm{Si}$ alloy
}

Maxime Delbove $^{\mathrm{a}, \mathrm{b}}$, Jean-Bernard Vogt ${ }^{\mathrm{a},{ }^{*}, \text { Jérémie Bouquerel }^{\mathrm{a}} \text {, Thierry Soreau }}{ }^{\mathrm{b}}$, François Primaux $^{\mathrm{b}}$

${ }^{a}$ Unité Matériaux Et Transformations, Université de Lille - 1 Sciences et Technologies / UMR CNRS / ENSCL / INRA, 59655 Villeneuve d'Ascq, France

${ }^{\mathrm{b}}$ Le Bronze Industriel, Z.I. voie de Châlons, RD 977, 51600 Suippes, France

* Corresponding author. Tel.: +33 3204340 35; fax: +33 320434040

E-mail addresses: jean-bernard.vogt@ensc-lille.fr (J.-B. Vogt)

\begin{abstract}
Low cycle fatigue tests were performed at room temperature to investigate the role of the microstructure of a $\mathrm{Cu}-\mathrm{Ni}-\mathrm{Si}$ alloy on the stress response to strain cycling and on the fatigue resistance. The cyclic accommodation consisted in a hardening followed by a softening. TEM analysis showed that in some grains dislocations remained isolated and confined between precipitates while in other grains dislocations piled up at $\delta-\mathrm{Ni}_{2} \mathrm{Si}$ precipitates and then cut them. Repetitive cutting allows their dissolution and formation of precipitate-free bands where the plastic deformation is localised. The Manson-Coffin diagram exhibited two regimes according to the proportion of grains involved in the plastic deformation accommodation.
\end{abstract}

\section{Keywords}

copper alloys - cyclic properties - low cycle fatigue - microstructure - microscopy

\section{Highlights}

Investigated $\mathrm{Cu}-\mathrm{Ni}-\mathrm{Si}$ contains $\delta-\mathrm{Ni}_{2} \mathrm{Si}$ nano precipitates $-\mathrm{Cyclic}$ hardening followed by softening is observed - Dissolution of $\delta-\mathrm{Ni}_{2} \mathrm{Si}$ results from repetitive cutting - Deformation is localised in precipitate-free bands

\section{Introduction}

A large amount of engineering applications, like railway equipment, marine hardware or lead frames, requires materials that exhibit high mechanical strength as well as good electrical and thermal conductivities. In that way, copper alloys are widely used although the enhancement of mechanical properties usually comes along with a decrease of the electrical performances $[1,2]$. To face this problem, oxide-dispersion-strengthened (ODS) copper alloys, where aluminium oxide nanoparticles are dispersed in the matrix, is one of the existing solutions [35]. However, their mechanical properties might not be enough for the cited applications. To overcome this aspect, precipitation hardened copper alloys have been developed, such as copper-beryllium alloys. Those latter exhibits a good balance between mechanical, thermal 
and electrical properties $[1,6]$. But due to the price and the toxicity of beryllium and its compounds, alternative copper alloys have been formulated. $\mathrm{Cu}-\mathrm{Ni}-\mathrm{Si}$ alloys, with a nickel content from 1.5 to $8.0 \mathrm{wt} . \%$ and a quantity of silicon included between 0.3 and $1.8 \mathrm{wt} . \%$, are known to be one of the best replacement options [4-6]. Their good property balance is mostly attributed to the formation of nanosized disc-shaped coherent $\delta-\mathrm{Ni}_{2} \mathrm{Si}$ precipitates identified by transmission electron microscopy (TEM) [7-11]. Currently, the scientific literature on these alloys mainly deals with the microstructure evolution combined with the optimisation of the mechanical (hardness and tensile properties) and electrical behaviour thanks to their elaboration process [12-18], their heat treatments [7,12,19-21] or their chemical composition [14,22-28]. The scope of applications of $\mathrm{Cu}-\mathrm{Ni}-\mathrm{Si}$ alloys contains the transport sector, in electric engines for example. It implies that they are submitted to cyclic loading andare therefore subjected to fatigue failure. The fatigue behaviour of $\mathrm{Cu}-\mathrm{Ni}-\mathrm{Si}$ alloys has however only been investigated in few articles, especially on high-cycle fatigue (HCF) [29,30]. Low cycle fatigue (LCF) was just briefly studied on polycrystalline material by Lockyer and Noble [29], and on Cu-Ni-Si single crystals by Fujii et al. [31]. The LCF behaviour seems to exhibit cyclic softening but has not been fully investigated at this point. Very recently, Goto et al. [32] investigated the role of microstructure on short crack propagation in a $\mathrm{Cu}-\mathrm{Ni}$-Si alloy by pointing out the importance of precipitation process. Indeed, particles and precipitate-free zones formed in their material as a result of the high level of Ni and their heat treatment. Both induced localised high stress/strain distribution which led to the crack initiation, followed by the growth along slip planes in grains sharing grain boundaries.

The aim of the present work is therefore to improve the knowledge on a $\mathrm{Cu}-\mathrm{Ni}-\mathrm{Si}$ alloy by providing a complete description of the LCF behaviour. The study of cyclic accommodation and of fatigue resistance will be linked to the microstructure investigated by scanning and transmission electron microscopes in order to propose a fatigue mechanism of the $\mathrm{Cu}-\mathrm{Ni}-\mathrm{Si}$ alloy.

\section{Material and experimental procedures}

The $\mathrm{Cu}-\mathrm{Ni}$-Si alloy used in the present work is a CuNi2Si (CW111C) provided by the company Le Bronze Industriel (France). The casted material was first solution treated around $950^{\circ} \mathrm{C}$ for $2 \mathrm{~h}$, then hot formed, rapidly quenched and finally aged at a temperature between $450^{\circ} \mathrm{C}$ and $500^{\circ} \mathrm{C}$ for a duration between $2 \mathrm{~h}$ and $4 \mathrm{~h}$. At last, the plate fatigue specimens were machined with a thickness of $3 \mathrm{~mm}$, a width of $6 \mathrm{~mm}$ and a gauge length of $12 \mathrm{~mm}$. This design of specimen ensures that no bending occurred during fatigue tests.

Before testing, each specimen was mechanically polished on both sides in order to remove the work-hardened surface due to the machining step. A mirror-like surface was obtained by using successively silicon carbide papers, diamond suspensions and colloidal silica suspension. For the metallographic investigation, samples were lastly etched during $10 \mathrm{~s}$ using a solution made of $5 \mathrm{~g}$ of $\mathrm{FeCl}_{3}, 50 \mathrm{~mL}$ of $\mathrm{HCl}$ and $100 \mathrm{~mL}$ of deionised water. 
Fatigue tests were carried out on an electromechanical Schenck Trebel RMC10 fatigue machine using an Instron 8800 mini-controller. Low cycle fatigue tests were conducted at room temperature under axial total strain control by using a $10 \mathrm{~mm}$ gauge extensometer. $\mathrm{A}$ triangular waveform, a fully push-pull mode $\left(\mathrm{R}_{\varepsilon}=-1\right)$, a total strain variation $\left(\Delta \varepsilon_{t}\right)$ value included between $0.6 \%$ and $1.5 \%$, and a constant strain rate of $4.10^{-3} \mathrm{~s}^{-1}$ have been selected as testing parameters.

The fatigue life $\mathrm{N}_{\mathrm{f}}$ has been defined as the number of cycles necessary to reach a difference higher than $25 \%$ between the maximum stress and the absolute value of the minimum stress during a cycle. The reference loop for the measurement of strain components and stress values was that recorded at $80 \%$ of the fatigue life.

The scanning electron microscopy (SEM) observations were conducted at an accelerating voltage of $20 \mathrm{kV}$ on a FEI Quanta 400 tungsten-SEM fitted with an electron backscatter diffraction (EBSD) detector from Oxford Instrument. TEM observations were performed on a Philips CM30 at an operating voltage of $300 \mathrm{kV}$, while automated crystal orientation mapping (ACOM-TEM) were conducted at an accelerating voltage of $200 \mathrm{kV}$ on a FEI Tecnai G2-20 equipped with the ASTAR $^{\mathrm{TM}}$ acquisition system developed by NanoMEGAS $[33,34]$. TEM thin foils were beforehand prepared by jet-polishing using Struers D2 commercial solution at $15 \mathrm{~V}$ and $15^{\circ} \mathrm{C}$. The orientation data was post-treated using the TSL OIM ${ }^{\mathrm{TM}}$ Analysis 7 commercial software provided by EDAX.

\section{Results and analysis}

\subsection{Metallographic characterisation and microstructure}

The microstructure of the material is shown in Fig. 1. EBSD data reveal that the studied alloy presents equiaxed grains with a size ranging from 20 to $50 \mu \mathrm{m}$. A large number of annealing twins is also observed.

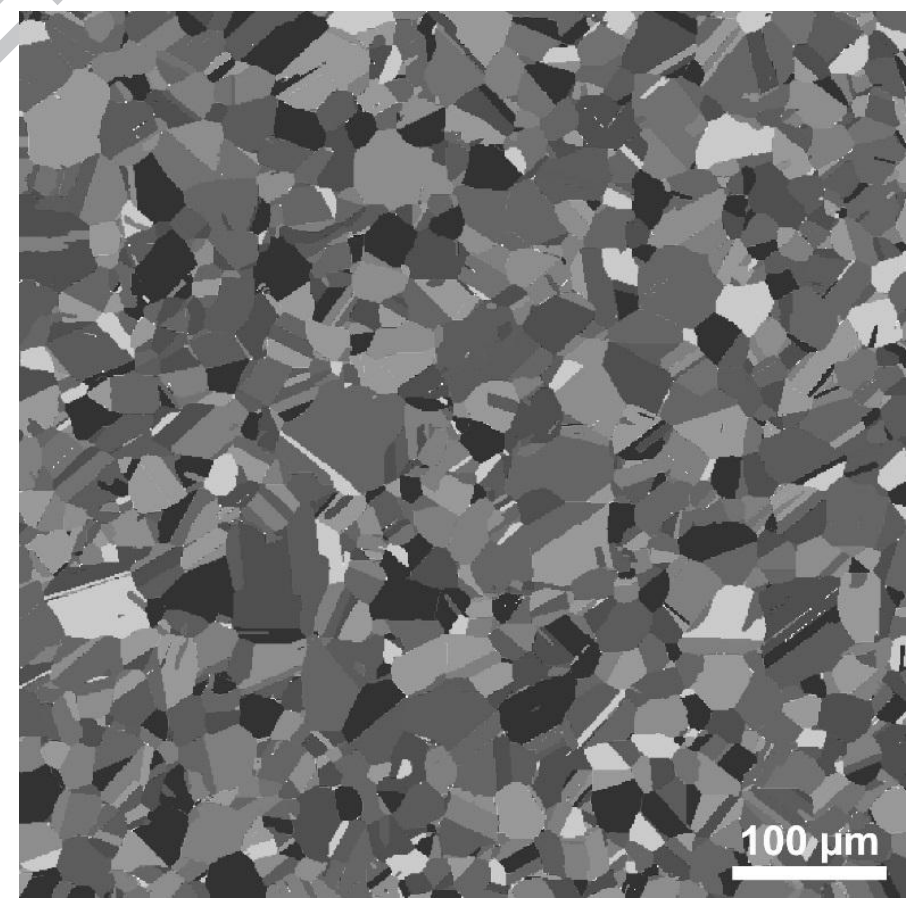


Fig. 1. EBSD unique grain map of the studied $\mathrm{Cu}-\mathrm{Ni}-\mathrm{Si}$ alloy

Concerning the precipitates formed during the aging treatment, they have been identified by using selected area diffraction mode in TEM. Disc-like $\delta-\mathrm{Ni}_{2} \mathrm{Si}$ intended for the hardening of the alloy have been indeed detected. The precipitate density is high and their width is close to $5 \mathrm{~nm}$. For example, Fig. 2 shows the dark field micrograph and the diffraction pattern for a beam direction parallel to $\langle 111\rangle_{\mathrm{Cu}}$. The bright spots correspond to the diffraction of the copper matrix whereas the dotted star pattern is due to the diffraction of the three variants of $\delta-\mathrm{Ni}_{2} \mathrm{Si}$. Moreover, the nature of the precipitates is in agreement with the thermodynamic calculation of Lu et al [35].
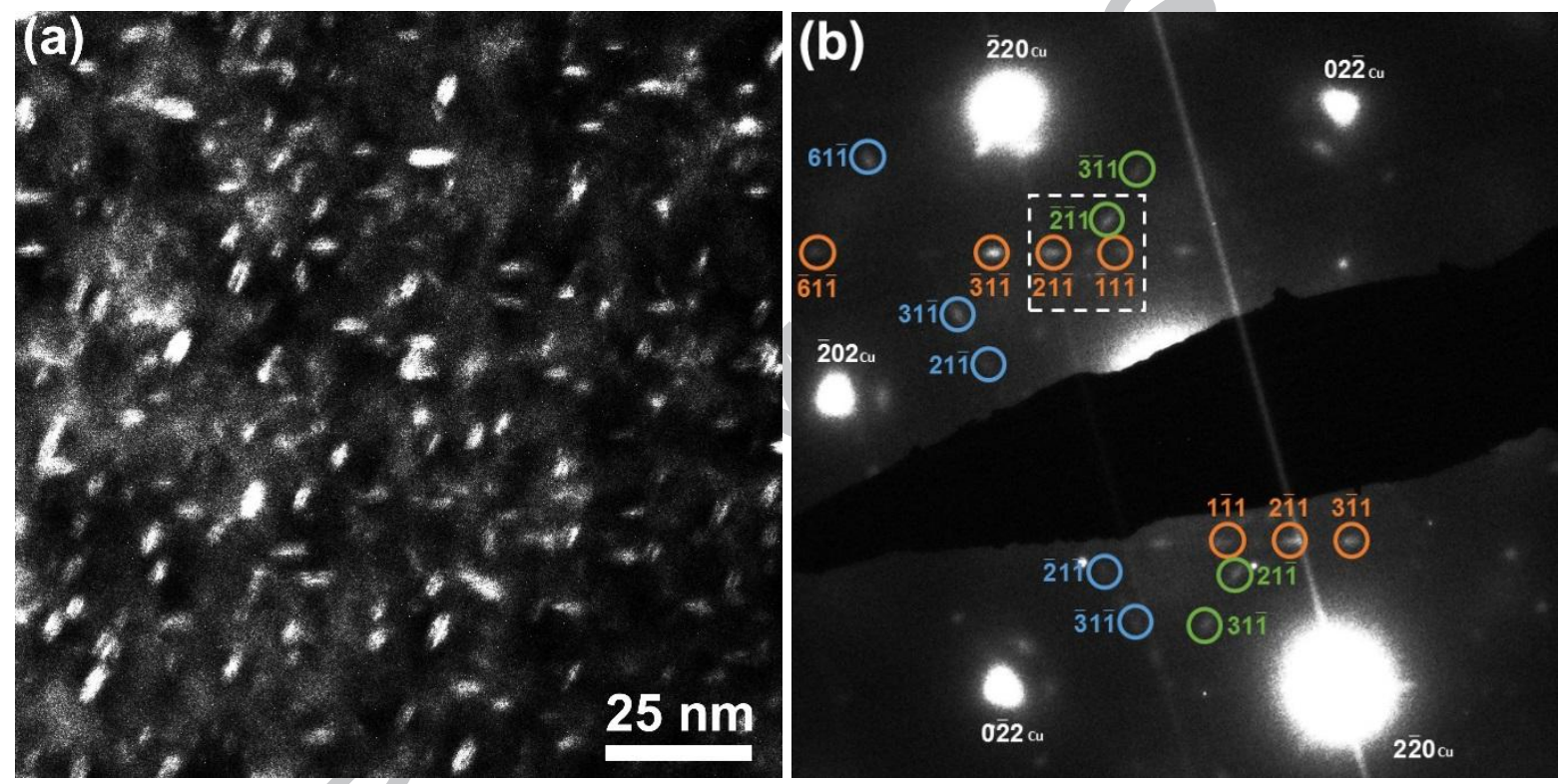

Fig. 2. Dark field micrograph (a) and corresponding selected zone on the indexed diffraction pattern (b) of the $\mathrm{Cu}-\mathrm{Ni}-\mathrm{Si}$ alloy for a beam direction parallel to $\langle 111\rangle_{\mathrm{Cu}}$

\subsection{Monotonic tensile behaviour}

Tensile tests have been carried out to characterise the monotonic properties of the material. Tests were performed up to fracture on a servo-hydraulic machine under displacement mode control in order to have a calculated strain rate equal to $10^{-3} \mathrm{~s}^{-1}$. An additional test where an extensometer was stuck to the gauge length was performed to measure accurately the Young modulus. Monotonic tensile properties values are summarised in Table 1.

Table 1. Monotonic tensile characteristics of the $\mathrm{Cu}-\mathrm{Ni}-\mathrm{Si}$ alloy

\begin{tabular}{|c|c|c|c|c|c|c|}
\hline $\mathrm{E}(\mathrm{GPa})$ & $\mathrm{YS}_{0.2} \%(\mathrm{MPa})$ & $\mathrm{UTS}(\mathrm{MPa})$ & $\mathrm{A}_{\mathrm{u}}(\%)$ & $\mathrm{A}(\%)$ & $\mathrm{n}$ & $\mathrm{K}(\mathrm{MPa})$ \\
\hline 130 & 540 & 700 & 11.5 & 12.7 & 0.12 & 930 \\
\hline
\end{tabular}


The material presents a good balance between a high ultimate tensile strength (UTS) and a uniform elongation $\left(A_{u}\right)$ higher than $10 \%$. But the low difference between $A$ and $A_{u}$ reveals a low toughness of the material. This is confirmed by the observations of the fracture surfaces. Fig. 3 clearly shows that the tensile fracture surface comprises a mixture of brittle and ductile zones. The surface presents at the same time respectively intergranular fracture and ductile dimples.
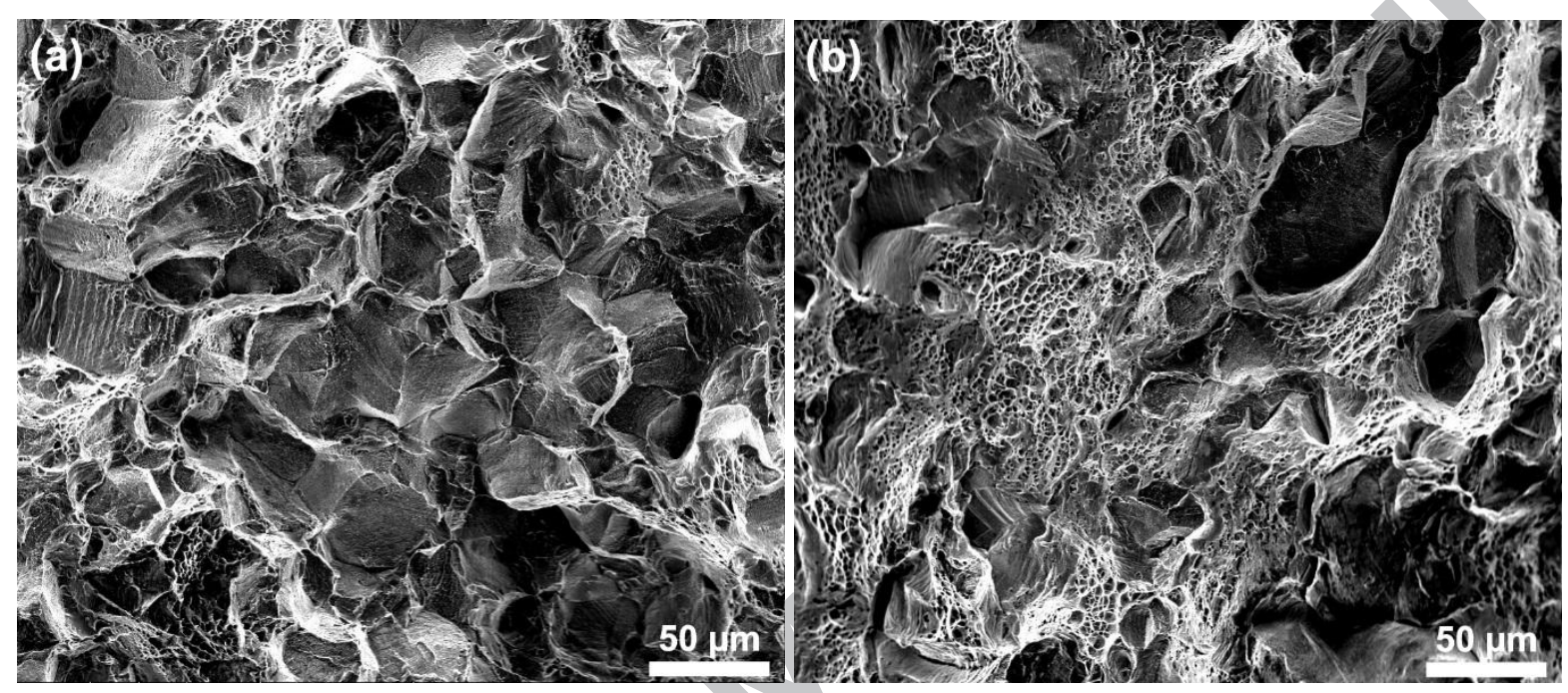

Fig. 3. SEM micrographs of the monotonic tensile fracture surface of the $\mathrm{Cu}-\mathrm{Ni}-\mathrm{Si}$ alloy presenting intergranular rupture (a) and dimples (b)

\subsection{Low cycle fatigue behaviour}

\subsubsection{Cyclic accommodation}

The graphical representations of the stress amplitude $\sigma_{\mathrm{a}}$ as a function of the number of cycles $\mathrm{N}$ in a logarithmic scale and versus the fatigue life fraction in linear scale are plotted in Fig. 4 for the different total strain variations. The behaviour during tensile and compressive phases was nearly symmetrical.

For the high total strain variation tests $\left(\Delta \varepsilon_{\mathrm{t}}=1.2 \%\right.$ and $\left.1.5 \%\right)$, the fatigue life of the alloy can be divided into four parts. At the beginning of the test, a hardening behaviour is observed during the first 50 cycles. This step is followed by a primary softening behaviour, until $20 \%$ of the fatigue life fraction. Then, a secondary softening step with a lower intensity occurs until $90 \%$ of the fatigue life fraction. At the end, the last $10 \%$ of the fatigue life fraction are attributed to the propagation of the main crack in the bulk. This LCF behaviour confirms the cyclic accommodation observed by Lockyer and Noble but not their fatigue life [29]. Their alloy, with a similar chemical composition but a different thermomechanical treatment (the as received commercial alloy was re-solution treated at $800{ }^{\circ} \mathrm{C}$ for $2 \mathrm{~h}$ and then aged at $450{ }^{\circ} \mathrm{C}$ for $2 \mathrm{~h}$ ), exhibits indeed a number of cycle to failure way lower than the one in the present study (for a test carried out at $1 \%$ total strain amplitude on hour-glass specimens). This difference can be attributed to the microstructure variation (grain size, precipitate size and density) resulting from the thermomechanical treatment. This result highlights the 
significance of the material process and initial microstructure descriptions for $\mathrm{Cu}-\mathrm{Ni}-\mathrm{Si}$ alloys.

At lower total strain variation $\left(\Delta \varepsilon_{\mathrm{t}}=0.8 \%\right)$, no hardening stage is observed at the beginning of the test and the alloy continuously softens during the cyclic loading at a rate close to the second softening step at high total strain variation. Moreover, at the lowest tested total strain variation $\left(\Delta \varepsilon_{\mathrm{t}}=0.6 \%\right)$, the softening effect is very slight. Therefore, for the considered conditions, the material exhibits no real stable state during the cyclic loading.
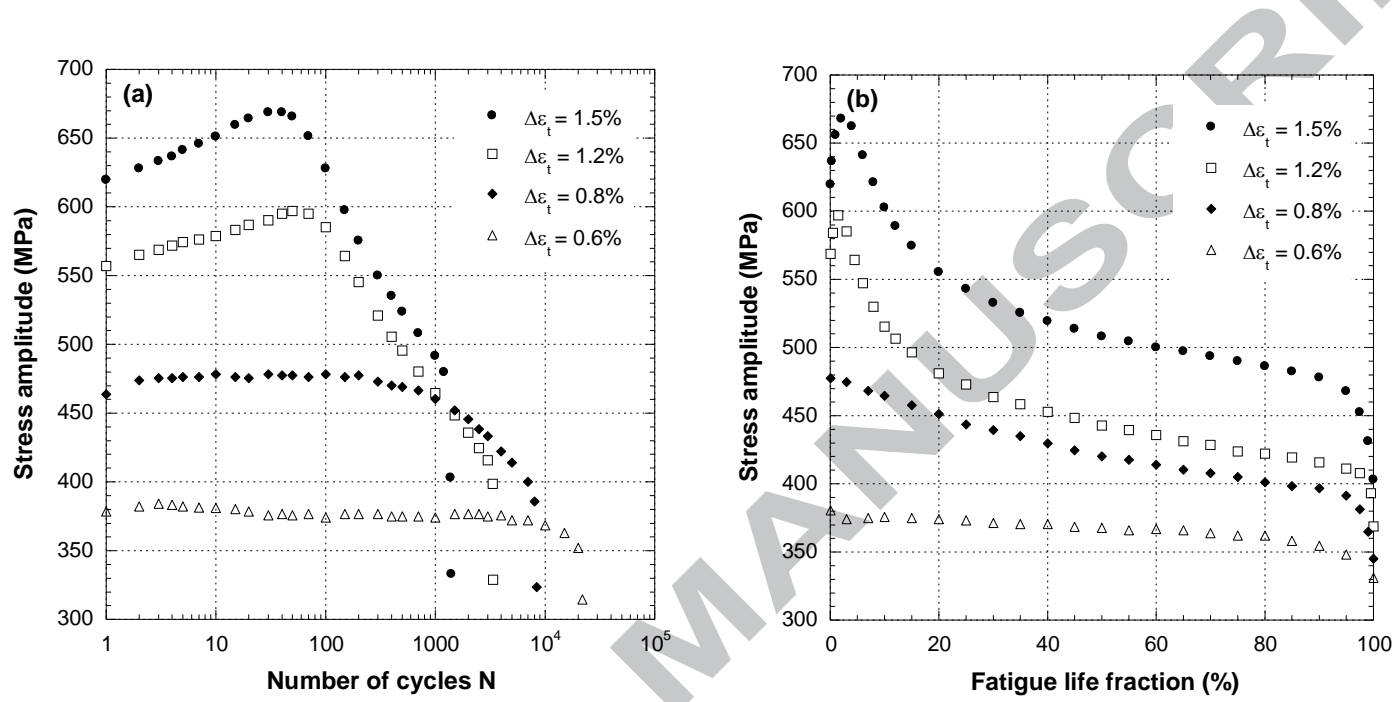

Fig. 4. Evolution of the cyclic stress amplitude versus the number of cycles (a) and the fatigue life fraction (b) for different total strain variations

To appreciate more accurately the hardening and softening, the evolution of plastic strain variation $\Delta \varepsilon_{\mathrm{p}}$ during cyclic loading has been plotted (Fig. 5).

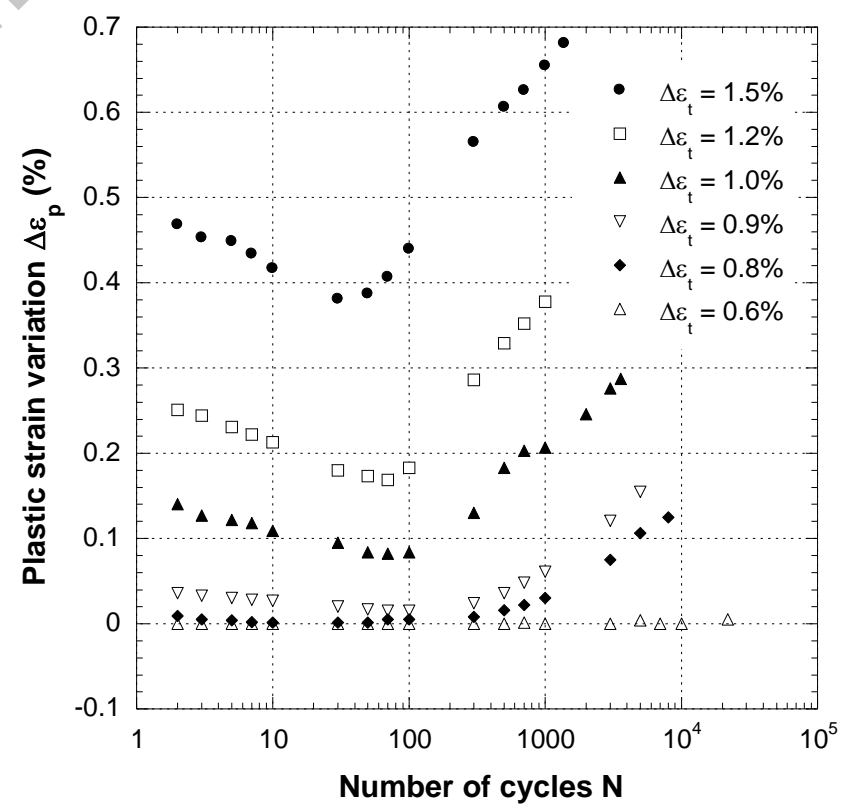


Fig. 5. Evolution of the cyclic plastic strain variation versus the number of cycles for different total strain variations

For a total strain variation $\Delta \varepsilon_{\mathrm{t}}$ included between 0.9 and $1.5 \%$, the plastic strain decreases at first and then increases, which correspond respectively to the hardening and softening steps. This clearly indicates that the hardening and softening are very strong. However, hysteresis loops exhibited a linear shape during the entire fatigue life for the test conducted at $\Delta \varepsilon_{\mathrm{t}}=0.6$ $\%$ and no macroplasticity has been observed. The absence of stabilised state needs to specify a criterion for the selection of the hysteresis loops for the drawing of the cyclic stress-strain curves presented in Fig. 6 . In the present case, it has been decided to measure strain and stress values on hysteresis loops recorded at the hardening peak and at the end of the softening period, just before the crack propagation period, which corresponds to $90 \%$ of the fatigue life. It can be clearly seen that the softening effect during cyclic loading is much more important than the slight hardening resulting from the beginning of fatigue testing.

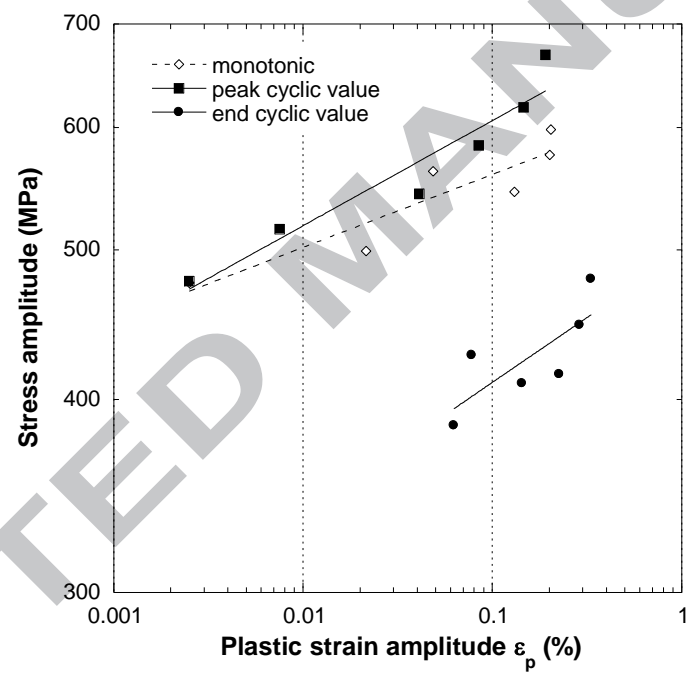

Fig. 6. Monotonic and cyclic stress-strain curves for the $\mathrm{Cu}-\mathrm{Ni}-\mathrm{Si}$ alloy tested at room temperature

\subsubsection{Fatigue resistance}

The graphical representation of the total, the plastic and the elastic strain variations (respectively $\Delta \varepsilon_{\mathrm{t}}, \Delta \varepsilon_{\mathrm{p}}$ and $\Delta \varepsilon_{\mathrm{e}}$ ) with the fatigue life is presented in Fig. 7a. The MansonCoffin relation (Eq. 1) must be considered according two regimes $\left(\Delta \varepsilon_{\mathrm{t}} \leq 1 \%\right.$ or $\left.\Delta \varepsilon_{\mathrm{t}}>1 \%\right)$ while only one regime can be considered for the Basquin relation (Eq. 2).

$$
\begin{aligned}
& \Delta \varepsilon_{\mathrm{p}}=\mathrm{K}_{\mathrm{p}}\left(\mathrm{N}_{\mathrm{f}}\right)^{\mathrm{C}_{\mathrm{p}}} \\
& \Delta \varepsilon_{\mathrm{e}}=\mathrm{K}_{\mathrm{e}}\left(\mathrm{N}_{\mathrm{f}}\right)^{\mathrm{C}_{\mathrm{e}}}
\end{aligned}
$$


The evolution of the stress amplitude $\sigma_{\mathrm{a}}$ versus the number of cycles to failure $\mathrm{N}_{\mathrm{f}}$ is also plotted in Fig. 7b. It follows the pseudo-Wöhler relation (Eq. 3).

$\sigma_{\mathrm{a}}=\mathrm{K}_{\mathrm{PW}}\left(\mathrm{N}_{\mathrm{f}}\right)^{\mathrm{C}_{\mathrm{PW}}}$

Finally, the plastic energy dissipated per cycle $\Delta \mathrm{W}_{\mathrm{p}}$, measured by the area inside the hysteresis loop, is represented against $\mathrm{N}_{\mathrm{f}}$ in Fig. 7c. As for the Manson-Coffin approach, two regimes must be considered $\left(\Delta \varepsilon_{\mathrm{t}} \leq 1 \%\right.$ or $\left.\Delta \varepsilon_{\mathrm{t}}>1 \%\right)$. The Golos and Ellyn relation (Eq. 4 ) has been employed to measure the fatigue resistance of the alloy.

$\Delta \mathrm{W}_{\mathrm{p}}=\mathrm{K}_{\mathrm{W}_{\mathrm{p}}}\left(\mathrm{N}_{\mathrm{f}}\right)^{\mathrm{C}_{\mathrm{p}}} \propto \sigma_{\mathrm{a}} \cdot \Delta \varepsilon_{\mathrm{p}}$

The Manson-Coffin relation and the plastic energy dissipated per cycle approach appear to be the two best criteria to quantify the fatigue resistance of the tested $\mathrm{Cu}-\mathrm{Ni}-\mathrm{Si}$ alloy, but two distinct regimes $\left(\Delta \varepsilon_{\mathrm{t}} \leq 1 \%\right.$ or $\left.\Delta \varepsilon_{\mathrm{t}}>1 \%\right)$ have to be considered.
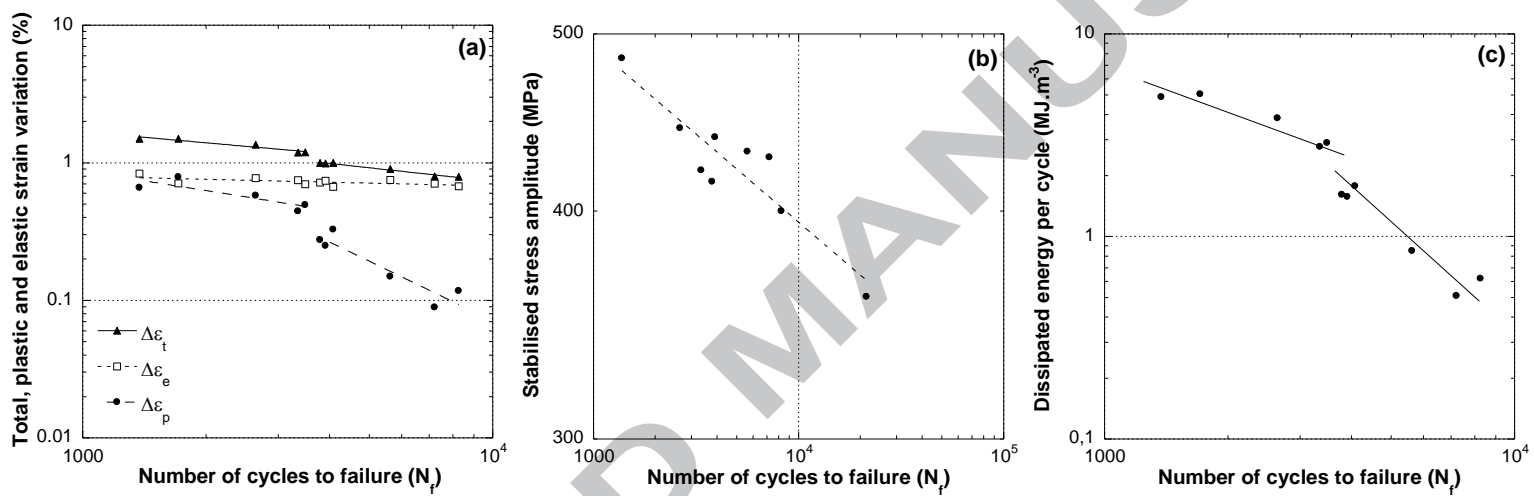

Fig. 7. Fatigue resistance diagrams of the $\mathrm{Cu}-\mathrm{Ni}$-Si alloy: (a) Manson-Coffin diagram, (b)

Pseudo-Wöhler diagram, (c) energy diagram

In the four cited equations, the factors $\mathrm{K}$ and $\mathrm{C}$ represent respectively the coefficient and the exponent of fatigue resistance associated to the relation. All these results are summarised in Table 2.

Table 2. Fatigue resistance coefficients and exponents of the $\mathrm{Cu}-\mathrm{Ni}-\mathrm{Si}$ alloy

\begin{tabular}{|c|c|c|c|c|c|c|c|c|}
\hline & Mans & Coffin & & uin & Pseud & V̈̈hler & Golos & Ellyn \\
\hline $\begin{array}{l}\Delta \varepsilon_{t} \\
(\%)\end{array}$ & $\begin{array}{l}\mathrm{K}_{\mathrm{p}} \\
(\%)\end{array}$ & $\mathrm{C}_{\mathrm{p}}$ & $\begin{array}{c}\mathrm{K}_{\mathrm{e}} \\
(\%)\end{array}$ & $\mathrm{C}_{\mathrm{e}}$ & $\begin{array}{c}\mathrm{K}_{\mathrm{PW}} \\
(\mathrm{MPa})\end{array}$ & $\mathrm{C}_{\mathrm{PW}}$ & $\begin{array}{c}\mathrm{K}_{\mathrm{Wp}_{\mathrm{p}}} \\
\left(\mathrm{GJ} \cdot \mathrm{m}^{-3}\right)\end{array}$ & $\mathrm{C}_{\mathrm{Wp}_{\mathrm{p}}}$ \\
\hline$\leq 1$ & 41700 & -1.44 & \multirow{2}{*}{1.30} & \multirow{2}{*}{-0.070} & \multirow{2}{*}{958} & \multirow{2}{*}{-0.096} & 545 & -1.54 \\
\hline$\geq 1.2$ & 23.1 & -0.474 & & & & & 0.569 & -0.646 \\
\hline
\end{tabular}

\subsubsection{Crack initiation}

Slip marks produced by cyclic loading at the external surface of the fractured specimens at $\Delta \varepsilon_{\mathrm{t}}=0.8 \%$ and $\Delta \varepsilon_{\mathrm{t}}=1.5 \%$ are displayed Fig. 8 . The external surfaces are covered by extrusions the density of which was very high at high strain range. Compared with pure polycrystalline copper [36], they appeared much thinner and much straighter and had a similar aspect to those produced in other precipitate-strengthened alloys $[37,38]$. This suggests that 
cross slip is disfavoured for planar slip. As well, secondary slip was frequently observed in the highly strained specimens.
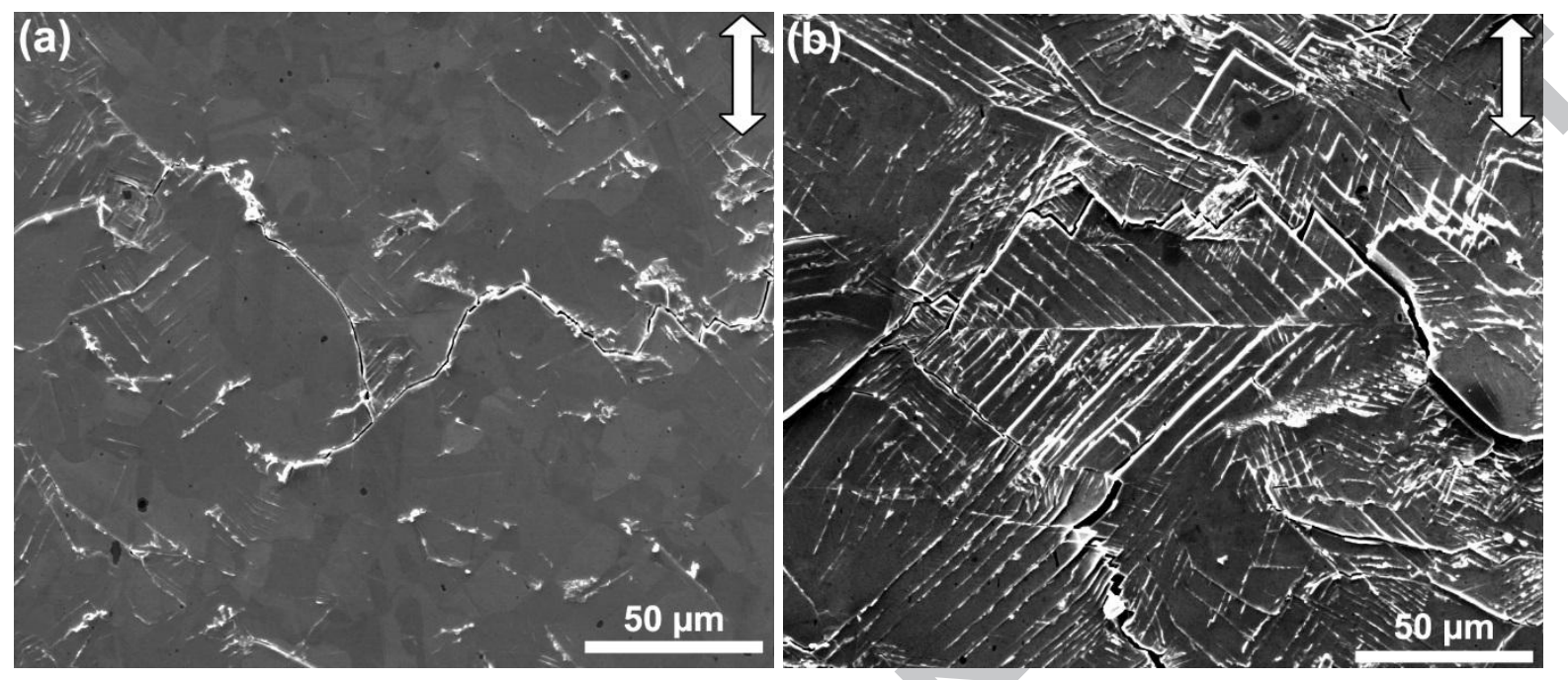

Fig. 8. SE-SEM micrographs of specimen surfaces after failure at $\Delta \varepsilon_{\mathrm{t}}=0.8 \%$ (a) and at $\Delta \varepsilon_{\mathrm{t}}=$ $1.5 \%$ (b). The double white arrow indicates the loading axis.

The evolution of the slip marks pattern has been analysed thanks to interrupted tests at different fatigue life fractions for the test performed at $\Delta \varepsilon_{t}=1.5 \%$. The corresponding SEM observations are gathered together in Fig. 9. During the hardening period, the slip activity developed in one slip system in some grains while the other ones appeared less active or may be inactive. Fig. 9a shows that the slip marks formed within the activated grains after 25 cycles consist of straight slip bands the emergence of which is mostly weak. Among them, a few ones are more developed. After 50 cycles (Fig. 9b), that is at the transition between the hardening and the softening periods, the slip marks pattern is nearly the same but more pronounced and secondary slip started occurring. With further cycling, the slip band density and the slip band height increase then with the number of cycles until the specimen fracture. Crack initiation took place at slip band roots and propagation was mainly transgranular and occasionally intergranular. The crack mode is similar to the one observed in $\alpha$-brass $[39,40]$. 


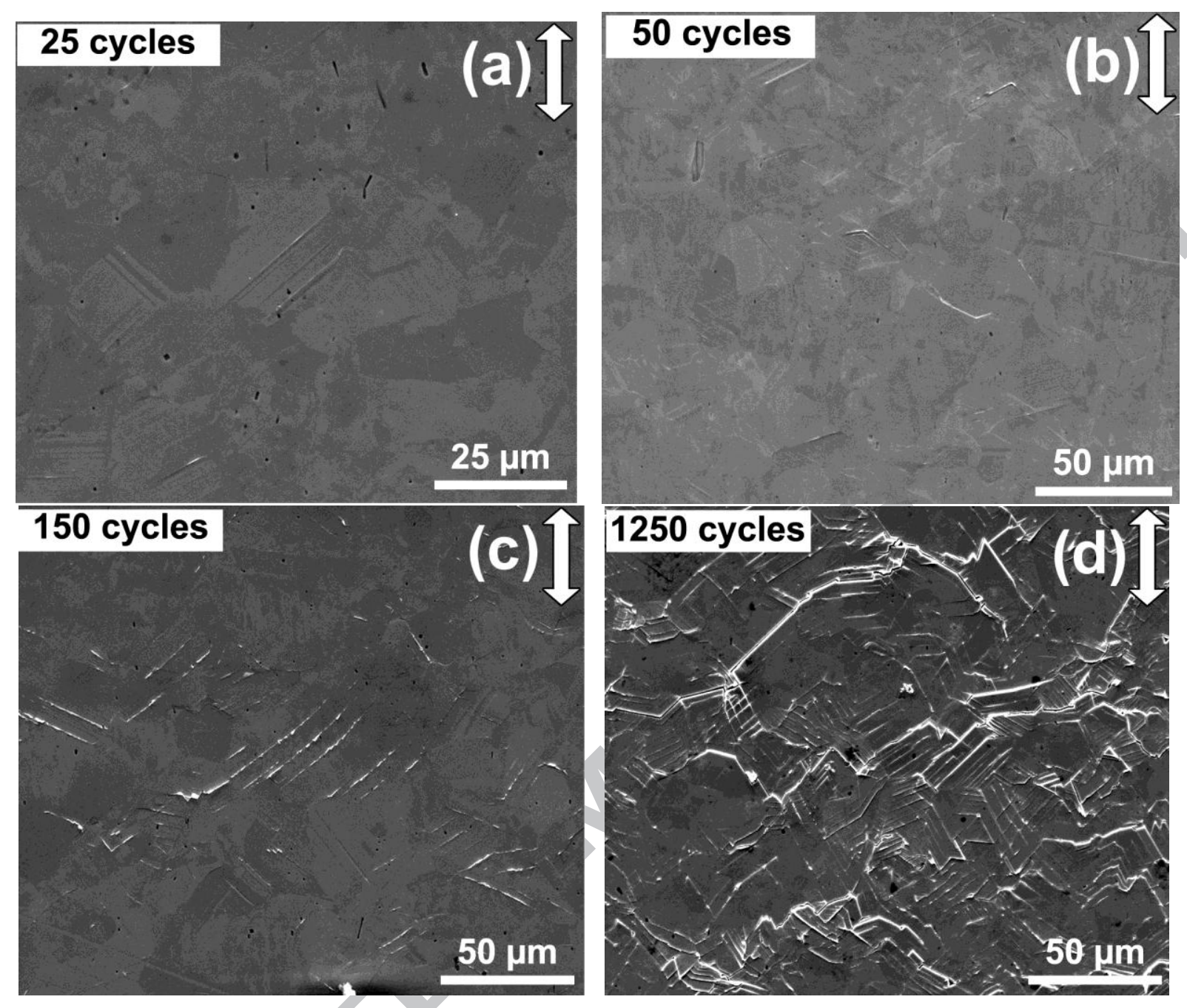

Fig. 9. SE-SEM micrograph evolution of the specimen surface as a function of the number of cycles for a test conducted at $\Delta \varepsilon_{\mathrm{t}}=1.5 \%$. The double white arrow indicates the loading axis.

\subsubsection{TEM investigation}

TEM thin foils were taken off from post-mortem specimens to study the dislocation structure after fatigue testing. Contrary to fatigued polycrystalline copper [41] or ODS copper alloys [42], the cyclic deformation did not result in well-formed dislocations arrangements such as walls or cells in the investigated strain ranges. Globally, the grains were featuring two kinds of deformation structures. The first one is shown in Fig. 10, where some grains contained a high density of dislocations segments or debris next to the $\delta-\mathrm{Ni}_{2} \mathrm{Si}$ precipitates but dislocations remained isolated and did not rearrange into a low energy dislocation structure. In addition, some dislocations appear to be pinned between two precipitates. The alloy fatigued at $\Delta \varepsilon_{\mathrm{t}}=0.6 \%$ had all the grains with this structure observed in Fig. 10. 


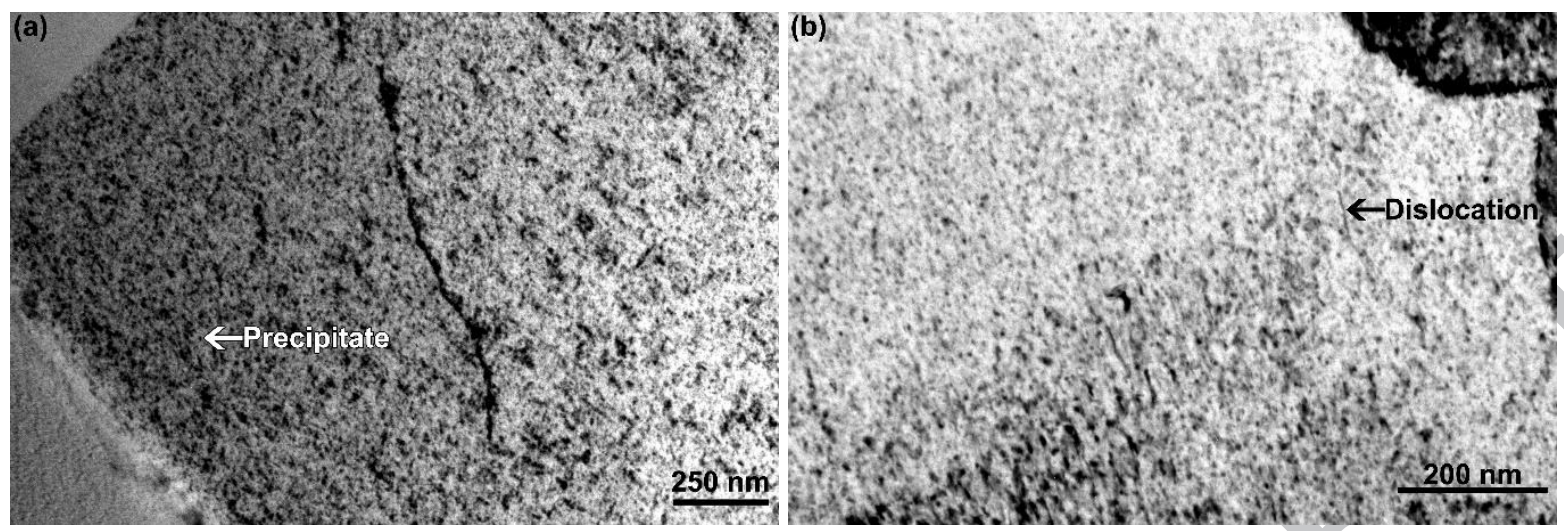

Fig. 10. TEM observations of fatigued Cu-Ni-Si specimens after failure at $\Delta \varepsilon_{t}=0.6 \%$ (a) and at $\Delta \varepsilon_{\mathrm{t}}=1.5 \%(\mathrm{~b})$

For the other specimens tested at strain ranges higher than $\Delta \varepsilon_{\mathrm{t}}=0.6 \%$, in addition to the former observations, the other grains were decorated with a grid pattern of white bands as shown in Fig. 11. The more the specimen is strained, the higher is the amount of grains presenting this pattern. These bands crossed the entire grain from grain boundary to opposite one and propagated from neighbouring grains or twins. Close observations showed that they were free of precipitates.
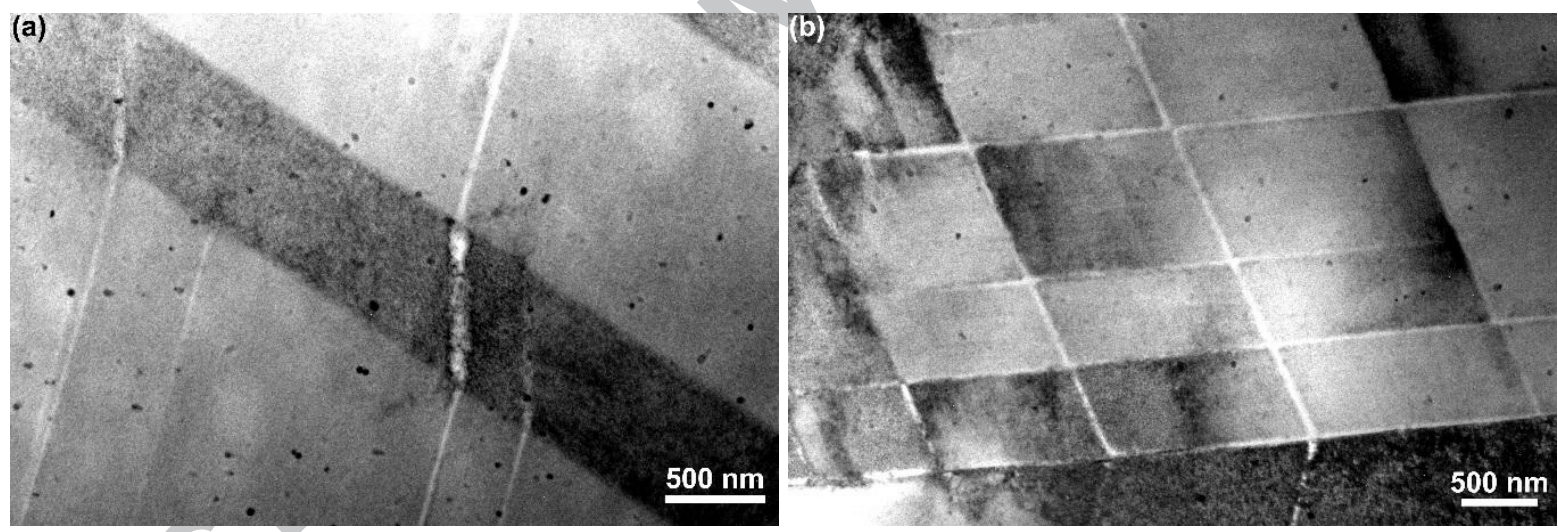

Fig. 11. TEM micrographs of a fatigued $\mathrm{Cu}-\mathrm{Ni}-\mathrm{Si}$ specimen (after failure at $\Delta \varepsilon_{\mathrm{t}}=1.5 \%$ ) showing bands without precipitates

The nature of the white precipitate-free bands has been determined using the ACOM-TEM technique. A zone $4 \mu \mathrm{m}^{2}$ in area including precipitate-free bands was scanned at a $5 \mathrm{~nm}$ step with the ASTAR ${ }^{\mathrm{TM}}$ software. Fig. 12a is virtual bright field image and Fig. $12 \mathrm{~b}$ is the inverse pole figure for copper crystals. No misorientation is pointed out between the band and the matrix, or is below the angular resolution of the system, evaluated at $1^{\circ}$ with the selected experimental conditions [34]. It is therefore clearly concluded that these precipitate-free bands are not deformation twins but intensive slip bands. 

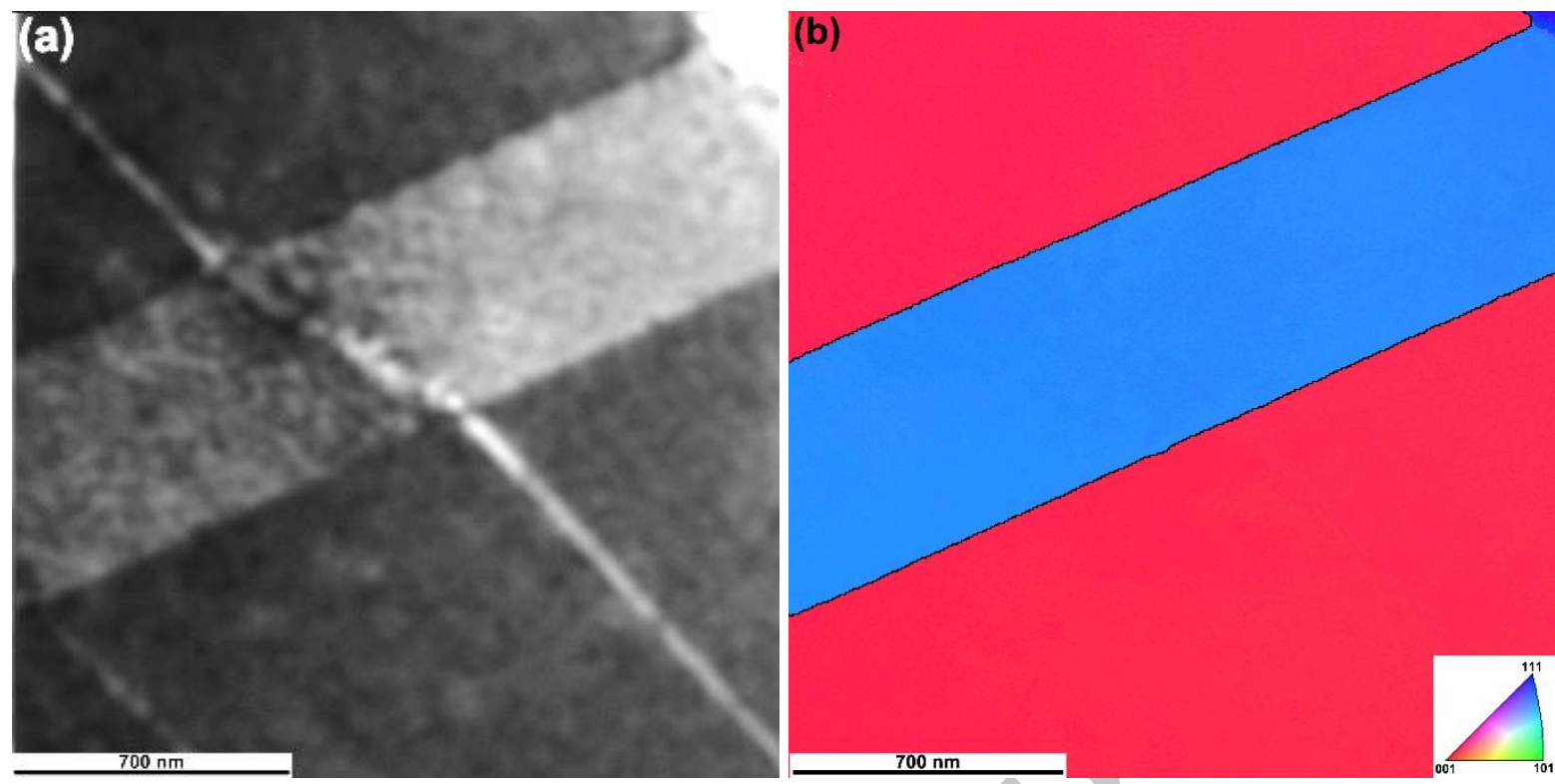

Fig. 12. ACOM-TEM virtual brigth-field image (a) and corresponding inverse pole figure map (b) of a zone scanned with a $5 \mathrm{~nm}$ step containing precipitate-free bands

\section{Discussion}

The present investigation which aimed at identifying the low cycle fatigue properties of a $\mathrm{Cu}$ $\mathrm{Ni}-\mathrm{Si}$ alloy shows that the material exhibited high stress values. This is the result of the efficient hardening heat treatment that precipitated $\delta-\mathrm{Ni}_{2} \mathrm{Si}$ nanosized particles. Compared to other ODS copper such as $\mathrm{Cu}-\mathrm{Al}_{2} \mathrm{O}_{3}$ material, the Young modulus as well the yield stress of the considered $\mathrm{Cu}-\mathrm{Ni}$-Si alloy are respectively $30 \%$ and $65 \%$ higher [3]. Both materials exhibit nearly the same size range of nanoparticles but the interaction of dislocations with the precipitates is different. In $\mathrm{Al}_{2} \mathrm{O}_{3}$ ODS copper alloys, dislocations can bypass the $\mathrm{Al}_{2} \mathrm{O}_{3}$ particles but do not interact similarly with the $\delta-\mathrm{Ni}_{2} \mathrm{Si}$ precipitates of the tested $\mathrm{Cu}-\mathrm{Ni}-\mathrm{Si}$. Due to their coherency with the copper matrix $[7,43]$ and their high volume fraction, the interaction of dislocations with $\delta-\mathrm{Ni}_{2} \mathrm{Si}$ nanosized particles is cutting [44]. This impacts the cyclic stress response to strain cycling and the fatigue life dependence with the applied strain of the $\mathrm{Cu}-\mathrm{Ni}-\mathrm{Si}$ alloy.

For the lowest strain range test $\left(\Delta \varepsilon_{\mathrm{t}}=0.6 \%\right)$ where the stress amplitude is nearly constant during cycling, all the grains exhibited the same deformation structure. Dislocations moved under the applied shear stress and remained confined in their slip plane, so that no substructure formed. The plastic deformation is so small that dislocations accommodated it just by a quasi-reversible motion and did not interact between them. As well, the dislocation displacement is less than the average distance between precipitates so that they nearly did not interact with them.

For the other tests, the mechanical response, the cyclic stress-strain curve and the MansonCoffin curve, points out two regimes whether tests were performed in the range $1.2 \%-1.5 \%$ or in the range $0.8 \%-1.0 \%$. If we consider the strain variations ranging from $1.2 \%$ to $1.5 \%$, that is a situation totally opposite to the one described above, the assigned deformation is so high that most of all the grains are activated and accommodate large plastic strain. The number of involved dislocations is high and should glide on large distance but have a limited mean free path because of the high density of nanoscale $\delta-\mathrm{Ni}_{2} \mathrm{Si}$ precipitates [44]. A strong 
hardening is thus observed as the result of dislocations-dislocations and dislocationsprecipitates interactions. At the same time, as the dislocations pile up at precipitates, an increasing shear stress is generated. When the critical value for shearing is reached, here after 50 first cycles (the cyclic peak stress), then precipitates are cut providing a path for dislocations. The blocked dislocations can therefore escape leading to stress relaxation and to the observed strong primary cyclic softening in Fig. 4. A strong localisation of plastic deformation occurs in narrow bands which behave as persistent slip bands in pure copper. Such bands have already been reported under LCF in a Cu-Ni-Si single crystal [31], under LCF and high-cycle fatigue in a polycrystalline $\mathrm{Cu}-\mathrm{Ni}-\mathrm{Si}$ alloy [29], but also in other precipitate hardened copper $(\mathrm{Cu}-\mathrm{Co})[45,46]$, aluminium $[37,47,48]$ or nickel alloys $[38,49]$. The moderate secondary softening corresponds to dislocation behaviour in these bands and it turns out that annihilation process is still prevailing and that equilibrium is not reached. Therefore, due to successive cutting of $\delta-\mathrm{Ni}_{2} \mathrm{Si}$ by the dislocations going forward and backward in the softening stage, precipitates are reduced under the critical size of stability, leading to their dissolution into the matrix and finally to the formation of precipitate-free bands.

When the applied strain is moderate, typically $\Delta \varepsilon_{t}=0.8 \%$ or $0.9 \%$, most grains accommodate the plastic deformation. Since the assigned deformation is quite small, dislocations glide on rather short distance and are not obstructed as much as in the range of deformation $\Delta \varepsilon_{\mathrm{t}}=1.2 \%$ - $1.5 \%$, which gives rise to a very moderate or even to a quasi-absence of hardening. Only few well oriented grains have dislocations moving on larger distance with a limited mean free path as described previously. These grains cyclically harden but since they are in minority, the macroscopic average cyclic response is a cyclic softening. The transition between the two regimes in the cyclic accommodation curves diagram and in the Manson-Coffin diagram low and high strain regimes reflects the proportion of grains involved in the hardening/softening process is majority.

\section{Conclusion}

The investigation of the microstructure of the tested $\mathrm{Cu}-\mathrm{Ni}-\mathrm{Si}$ alloy has exhibited a high density of $\delta-\mathrm{Ni}_{2} \mathrm{Si}$ precipitates resulting in the fatigue properties summarised as follows.

1. The cyclic accommodation of the alloy is composed of a hardening step at the beginning of the test, follow by a continuous softening until the specimen fracture. Moreover, two plastic regimes have to be considered $\left(0.8 \% \leq \Delta \varepsilon_{\mathrm{t}} \leq 1.0 \%\right.$ and $\left.1.2 \% \leq \Delta \varepsilon_{\mathrm{t}} \leq 1.5 \%\right)$ in order to characterise its fatigue resistance. Planar slip is favoured in this alloy and the slip band density at the surface increase with the strain level and the number of cycles. Finally, grains exhibit two different strain patterns. The first one presents lots of short dislocations but not rearranged into a sub structure. The other one is composed of precipitate-free bands and only appeared if $\Delta \varepsilon_{\mathrm{t}}$ is higher than $0.8 \%$. Moreover, the number of grains exhibiting the second strain patter increased with the strain level.

2. The microstructure evolution during cyclic loading can be described as follow. At the lowest tested strain range $\left(\Delta \varepsilon_{\mathrm{t}}=0.6 \%\right)$, each grain can accommodate the deformation by quasi reversible slip of dislocations. At higher strain ranges $\left(\Delta \varepsilon_{t} \geq 0.8 \%\right)$, some grains present dislocations piled up on precipitates, leading to an alloy hardening. Then precipitate cutting can occur resulting in a cyclic softening of the alloy. The successive cutting of the precipitates 
leads to their dissolution into the matrix and then precipitate-free bands where the deformation is localised. The two regimes exhibited by the Manson-Coffin diagram reflect the proportion of grains involved in the plastic deformation accommodation. The above described presented phenomenon are indeed localised in a few number of grains at low strain rates $(0.8$ $\left.\% \leq \Delta \varepsilon_{\mathrm{t}} \leq 1.0 \%\right)$, whereas they are generalised at higher strain ranges $\left(1.2 \% \leq \Delta \varepsilon_{\mathrm{t}} \leq 1.5 \%\right)$.

\section{Acknowledgments}

This work has been financially supported by Bpifrance and the Conseil Regional du Nord-Pas de Calais.

The authors thank A. Addad, D. Creton and J. Golek for their technical assistance.

The SEM and TEM national facility in Lille (France) is supported by the Conseil Regional du Nord-Pas de Calais, the European Regional Development Fund (ERDF).

\section{References}

[1] C.A. Isbell, Copper Alloys, in: Ullmann's Encyclopedia of Industrial Chemistry, Volume 10, Wiley-VCH Verlag GmbH \& Co. KGaA, 2000: pp. 229-272. doi:10.1002/14356007.a07_525

[2] J.R. Davis, ed., ASM Specialty Handbook: Copper and Copper Alloys, ASM International, Materials Park, OH, USA, 2001. http://www.asminternational.org/materials-resources/results//journal_content/56/10192/16857723/PUBLICATION

[3] A. Daoud, J.-B. Vogt, E. Charkaluk, J. Bouquerel, L. Zhang, J.-C. Biasci, Anisotropy effects on the tensile and fatigue behaviour of an oxide dispersion strengthened copper alloy, Materials Science and Engineering: A. 534 (2012) 640-648. doi:10.1016/j.msea.2011.12.021

[4] M. Li, S.J. Zinkle, 4.20 Physical and Mechanical Properties of Copper and Copper Alloys, Comprehensive Nuclear Materials. 4 (2012) 667-690. doi:10.1016/B978-0-08056033-5.00122-1

[5] I. Altenberger, H.-A. Kuhn, H.R. Müller, M. Mhaede, M. Gholami-Kermanshahi, L. Wagner, Material properties of high-strength beryllium-free copper alloys, International Journal of Materials and Product Technology. 50 (2015) 124-146. doi:10.1504/IJMPT.2015.067820

[6] H.-A. Kuhn, I. Altenberger, A. Käufler, H. Hölzl, M. Fünfer, Properties of High Performance Alloys for Electromechanical Connectors, in: L. Collini (Ed.), Copper Alloys - Early Applications and Current Performance - Enhancing Processes, InTech, 2012: pp. 51-68. doi:10.5772/1912

[7] S.A. Lockyer, F.W. Noble, Precipitate structure in a Cu-Ni-Si alloy, Journal of Materials Science. 29 (1994) 218-226. doi:10.1007/BF00356596

[8] R. Monzen, C. Watanabe, Microstructure and mechanical properties of $\mathrm{Cu}-\mathrm{Ni}-\mathrm{Si}$ alloys, Materials Science and Engineering: A. 483-484 (2008) 117-119. doi:10.1016/j.msea.2006.12.163

[9] T. Hu, J.H. Chen, J.Z. Liu, Z.R. Liu, C.L. Wu, The crystallographic and morphological 
evolution of the strengthening precipitates in $\mathrm{Cu}-\mathrm{Ni}-\mathrm{Si}$ alloys, Acta Materialia. 61 (2013) 1210-1219. doi:10.1016/j.actamat.2012.10.031

[10] Y. Jia, M. Wang, C. Chen, Q. Dong, S. Wang, Z. Li, Orientation and diffraction patterns of $\delta$-Ni2Si precipitates in $\mathrm{Cu}-\mathrm{Ni}$-Si alloy, Journal of Alloys and Compounds. 557 (2013) 147-151. doi:10.1016/j.jallcom.2012.12.154

[11] X.-P. Xiao, B.-Q. Xiong, G.-J. Huang, L. Cheng, L.-J. Peng, Q.-M. Liang, Microstructure and properties of $\mathrm{Cu}-2.8 \mathrm{Ni}-0.6 \mathrm{Si}$ alloy, Rare Metals. 32 (2013) 228233. doi:10.1007/s12598-013-0056-7

[12] H.J. Ryu, H.K. Baik, S.H. Hong, Effect of thermomechanical treatments on microstructure and properties of $\mathrm{Cu}$-base leadframe alloy, Journal of Materials Science. 35 (2000) 3641-3646. doi:10.1023/A:1004830000742

[13] V.C. Srivastava, A. Schneider, V. Uhlenwinkel, K. Bauckhage, Effect of thermomechanical treatment on spray formed $\mathrm{Cu}-\mathrm{Ni}-\mathrm{Si}$ alloy, Materials Science and Technology. 20 (2004) 839-848. doi:10.1179/026708304225017265

[14] S. Suzuki, N. Shibutani, K. Mimura, M. Isshiki, Y. Waseda, Improvement in strength and electrical conductivity of $\mathrm{Cu}-\mathrm{Ni}-\mathrm{Si}$ alloys by aging and cold rolling, Journal of Alloys and Compounds. 417 (2006) 116-120. doi:10.1016/j.jallcom.2005.09.037

[15] A.Y. Khereddine, F. Hadj Larbi, M. Kawasaki, T. Baudin, D. Bradai, T.G. Langdon, An examination of microstructural evolution in a $\mathrm{Cu}-\mathrm{Ni}-\mathrm{Si}$ alloy processed by HPT and ECAP, Materials Science and Engineering: A. 576 (2013) 149-155. doi:10.1016/j.msea.2013.04.004

[16] Y. Takagawa, Y. Tsujiuchi, C. Watanabe, R. Monzen, N. Tsuji, Improvement in Mechanical Properties of a Cu-2.0 mass\%Ni-0.5 mass\%Si-0.1 mass\%Zr Alloy by Combining Both Accumulative Roll-Bonding and Cryo-Rolling with Aging, Materials Transactions. 54 (2013) 1-8. doi:10.2320/matertrans.M2012207

[17] S. Lee, H. Matsunaga, X. Sauvage, Z. Horita, Strengthening of $\mathrm{Cu}-\mathrm{Ni}-\mathrm{Si}$ alloy using high-pressure torsion and aging, Materials Characterization. 90 (2014) 62-70. doi:10.1016/j.matchar.2014.01.006

[18] H.-S. Wang, H.-G. Chen, J.-W. Gu, C.-E. Hsu, C.-Y. Wu, Effects of heat treatment processes on the microstructures and properties of powder metallurgy produced $\mathrm{Cu}-$ $\mathrm{Ni}-\mathrm{Si}-\mathrm{Cr}$ alloy, Materials Science and Engineering: A. 619 (2014) 221-227. doi:10.1016/j.msea.2014.09.098

[19] Y.G. Kim, T.Y. Seong, J.H. Han, A.J. Ardell, Effect of heat treatment on precipitation behaviour in a Cu-Ni-Si-P alloy, Journal of Materials Science. 21 (1986) 1357-1362. doi:10.1007/BF00553275

[20] F. Huang, J. Ma, H. Ning, Y. Cao, Z. Geng, Precipitation in $\mathrm{Cu}-\mathrm{Ni}-\mathrm{Si}-\mathrm{Zn}$ alloy for lead frame, Materials Letters. 57 (2003) 2135-2139. doi:10.1016/S0167$577 \mathrm{X}(02) 01212-0$

[21] Z. Li, Z.Y. Pan, Y.Y. Zhao, Z. Xiao, M.P. Wang, Microstructure and properties of high-conductivity, super-high-strength $\mathrm{Cu}-8.0 \mathrm{Ni}-1.8 \mathrm{Si}-0.6 \mathrm{Sn}-0.15 \mathrm{Mg}$ alloy, Journal of Materials Research. 24 (2009) 2123-2129. doi:10.1557/jmr.2009.0251

[22] D. Zhao, Q.M. Dong, P. Liu, B.X. Kang, J.L. Huang, Z.H. Jin, Aging behavior of CuNi-Si alloy, Materials Science and Engineering: A. 361 (2003) 93-99. 
doi:10.1016/S0921-5093(03)00496-9

[23] C. Watanabe, F. Nishijima, R. Monzen, K. Tazaki, Mechanical Properties of Cu4.0wt\%Ni-0.95wt\%Si Alloys with and without $\mathrm{P}$ and $\mathrm{Cr}$ Addition, Materials Science Forum. 561-565 (2007) 2321-2324. doi:10.4028/www.scientific.net/MSF.561565.2321

[24] S. Chenna Krishna, J. Srinath, A.K. Jha, B. Pant, S.C. Sharma, K.M. George, Microstructure and Properties of a High-Strength Cu-Ni-Si-Co-Zr Alloy, Journal of Materials Engineering and Performance. 22 (2013) 2115-2120. doi:10.1007/s11665013-0482-6

[25] Q. Lei, Z. Li, C. Dai, J. Wang, X. Chen, J.M. Xie, et al., Effect of aluminum on microstructure and property of $\mathrm{Cu}-\mathrm{Ni}-\mathrm{Si}$ alloys, Materials Science and Engineering: A. 572 (2013) 65-74. doi:10.1016/j.msea.2013.02.024

[26] E. Lee, K. Euh, S.Z. Han, S. Lim, J. Lee, S. Kim, Tensile and electrical properties of direct aged $\mathrm{Cu}-\mathrm{Ni}-\mathrm{Si}-\mathrm{x} \% \mathrm{Ti}$ alloys, Metals and Materials International. 19 (2013) 183188. doi:10.1007/s12540-013-2007-0

[27] S.Z. Han, J.H. Gu, J.H. Lee, Z.P. Que, J.H. Shin, S.H. Lim, et al., Effect of V addition on hardness and electrical conductivity in $\mathrm{Cu}-\mathrm{Ni}-\mathrm{Si}$ alloys, Metals and Materials International. 19 (2013) 637-641. doi:10.1007/s12540-013-4002-X

[28] C. Watanabe, S. Takeshita, R. Monzen, Effects of Small Addition of Ti on Strength and Microstructure of a Cu-Ni-Si Alloy, Metallurgical and Materials Transactions A. 46 (2015) 2469-2475. doi:10.1007/s11661-015-2870-z

[29] S.A. Lockyer, F.W. Noble, Fatigue of precipitate strengthened Cu-Ni-Si alloy, Materials Science and Technology. 15 (1999) 1147-1153. doi:10.1179/026708399101505194

[30] Z. Sun, C. Laitem, A. Vincent, Dynamic embrittlement during fatigue of a $\mathrm{Cu}-\mathrm{Ni}-\mathrm{Si}$ alloy, Materials Science and Engineering: A. 528 (2011) 6334-6337. doi:10.1016/j.msea.2011.04.069

[31] T. Fujii, H. Kamio, Y. Sugisawa, S. Onaka, M. Kato, Cyclic Softening of Cu-Ni-Si Alloy Single Crystals under Low-Cycle Fatigue, Materials Science Forum. 654-656 (2010) 1287-1290. doi:10.4028/www.scientific.net/MSF.654-656.1287

[32] M. Goto, S.Z. Han, S.H. Lim, J. Kitamura, T. Fujimura, J.-H. Ahn, et al., Role of microstructure on initiation and propagation of fatigue cracks in precipitate strengthened $\mathrm{Cu}-\mathrm{Ni}-\mathrm{Si}$ alloy, International Journal of Fatigue. 87 (2016) 15-21. doi:10.1016/j.ijfatigue.2016.01.004

[33] NanoMEGAS, website. http://www.nanomegas.com/

[34] E.F. Rauch, M. Véron, Automated crystal orientation and phase mapping in TEM, Materials Characterization. 98 (2014) 1-9. doi:10.1016/j.matchar.2014.08.010

[35] D. Lu, J. Wang, A. Atrens, X. Zou, L. Lu, B. Sun, Calculation of Cu-rich part of CuNi-Si phase diagram, Transactions of Nonferrous Metals Society of China. 17 (2007) s12-s15. http://www.tnmsc.cn/paper/paperView.aspx?id=paper_14835

[36] J.-B. Vogt, E. Charkaluk, A. Daoud, L. Zhang, J.-C. Biasci, Effect of Al2O3 Dispersed Nanoparticles on the Fatigue Behaviour of Copper, in: LCF7 - Seventh International 
Conference on Low Cycle Fatigue, DVM Deutcher Verband für Materialforschung und -prüfung e.V., Aachen, Germany, 2013: pp. 327-332

[37] C. Calabrese, C. Laird, Cyclic stress - strain response of two-phase alloys Part I. Microstructures containing particles penetrable by dislocations, Materials Science and Engineering. 13 (1974) 141-157. doi:10.1016/0025-5416(74)90182-7

[38] R.E. Stoltz, A.G. Pineau, Dislocation-precipitate interaction and cyclic stress-strain behavior of a $\gamma^{\prime}$ strengthened superalloy, Materials Science and Engineering. 34 (1978) 275-284. doi:10.1016/0025-5416(78)90060-5

[39] C. Wejdemann, O.B. Pedersen, Atomic force microscopy of the intense slip localization causing fatigue crack initiation in polycrystalline brass, Materials Science and Engineering: A. 387-389 (2004) 556-559. doi:10.1016/j.msea.2003.12.095

[40] A. Sugeta, Y. Uematsu, K. Tomita, K. Hirose, M. Jono, Development of Fatigue Testing System for in-situ Observation by an Atomic Force Microscope and Small Fatigue Crack Growth Behavior in $\alpha$-Brass, JSME International Journal Series A. 49 (2006) 382-389. doi:10.1299/jsmea.49.382

[41] A.T. Winter, O.B. Pedersen, K.V. Rasmussen, Dislocation microstructures in fatigued copper polycrystals, Acta Metallurgica. 29 (1981) 735-748. doi:10.1016/00016160(81)90117-6

[42] J. Robles, K.R. Anderson, J.R. Groza, J.C. Gibeling, Low-Cycle fatigue of dispersionstrengthened copper, Metallurgical and Materials Transactions A. 25 (1994) 22352245. doi:10.1007/BF02652324

[43] C. Watanabe, R. Monzen, Coarsening of $\delta$-Ni2Si precipitates in a $\mathrm{Cu}-\mathrm{Ni}-\mathrm{Si}$ alloy, Journal of Materials Science. 46 (2011) 4327-4335. doi:10.1007/s10853-011-5261-x

[44] J.W. Martin, Precipitation Hardening, Second edition, Butterworth-Heinemann, 1998. http://www.sciencedirect.com/science/book/9780750638852

[45] D. Steiner, R. Beddoe, V. Gerold, G. Kostorz, R. Schmelczer, Particle dissolution during fatigue softening of age hardened $\mathrm{Cu}-\mathrm{Co}$ single crystals, Scripta Metallurgica. 17 (1983) 733-736. doi:10.1016/0036-9748(83)90483-0

[46] D. Steiner, V. Gerold, The fatigue behaviour of age-hardened Cu-2at.\%Co alloy, Materials Science and Engineering. 84 (1986) 77-88. doi:10.1016/00255416(86)90224-7

[47] W. Vogel, M. Wilhelm, V. Gerold, Persistent slip bands in fatigued peak aged Al-Zn$\mathrm{Mg}$ single crystals- $\mathrm{I}$. Development of dislocation microstructure and change of precipitation distribution, Acta Metallurgica. 30 (1982) 21-30. doi:10.1016/00016160(82)90040-2

[48] W. Vogel, M. Wilhelm, V. Gerold, Persistent slip bands in fatigued peak aged Al-ZnMg single crystals - II. Persistent slip bands in front of stage I fatigue cracks, Acta Metallurgica. 30 (1982) 31-35. doi:10.1016/0001-6160(82)90041-4

[49] M. Sundararaman, W. Chen, V. Singh, R.P. Wahi, TEM investigation of $\gamma^{\prime}$ free bands in nimonic PE16 under LCF loading at room temperature, Acta Metallurgica et Materialia. 38 (1990) 1813-1822. doi:10.1016/0956-7151(90)90293-P 


\section{Highlights}

Investigated $\mathrm{Cu}-\mathrm{Ni}$-Si contains a high density of $\delta-\mathrm{Ni}_{2} \mathrm{Si}$ precipitates - Cyclic hardening followed by softening is observed - Dissolution of $\delta-\mathrm{Ni}_{2} \mathrm{Si}$ results from repetitive cuttinglocalisation of deformation in precipitate-free bands 